\title{
火炎の浮力が盛期火災の換気量に及ぼす影響に関する基礎的検討 EFFECT OF FLAME BUOYANCY ON VENT FLOWS IN FULLY-DEVELOPED COMPARTMENT FIRES
}

\author{
中 村 正 寿*, 道越 真太郎**, 上川大 輔***, 長谷見 雄二**** \\ Masatoshi NAKAMURA, Shintaro MICHIKOSHI, Daisuke KAMIKAWA \\ and Yuji HASEMI
}

\begin{abstract}
The objective of this study is to discuss whether the flame buoyancy increases vent flows in fully-developed compartment fires. Vent flows of small-scale compartments with narrow frontages were measured. Different ceiling heights of the compartments were set to vary the work of flame buoyancy.

Greater vent flows were observed under the conditions with high ceiling. Calculated vent flows were more consistent with experimental data when the effect of flame buoyancy was taken account in, compared with when it was not considered. It was concluded that the flame buoyancy had the effect on vent flows of these compartments.
\end{abstract}

Keywords : Fully-developed compartment fire, Vent flow, Flame, Buoyancy, ceiling height, small scale experiment 盛期火災, 換気量, 火炎, 浮力, 天井高さ, 模型実験

\section{1. はじめに}

盛期火災時の換気量の予測に関する先駆的研究は川越 1) 2)によっ て行われた。川越は, 火災室内部のガス密度を一様と仮定し, 開口 部を挟んだ内側と外側の圧力差（開口部差圧）にベルヌーイ式を適 用して換気量を計算するモデル 1)を示した。また，その計算結果が $700 \sim 900^{\circ} \mathrm{C}$ の災室温度では温度依存性が無視できて開口因子 $A_{W} \sqrt{H_{W}}$ （ $A_{W}$ : 開口面積, $H_{W}$ : 開口丈 $)$ に比例すること 2)を示した。 その後, 換気量と開口因子の比例関係については Rockett3)が火災室 温度が $150^{\circ} \mathrm{C}$ 以上で温度依存性が小さくなることを予想し, Nakaya ら ${ }^{4)}$ は $300^{\circ} \mathrm{C}$ 以上で成立することを実大実験で確認した。

火災室内外のガス密度差に基づく開口部差圧から換気量を求める 考え方は火災室内のガス密度が高さ方向に変化する場合にも適用さ れ, Steckler5) 6) らと Nakaya ら 4)によって初期火災および盛期火災 の実大実験が行われ妥当性が示された。

近年では Quintiere ら 7)がドア開口・窓開口を考慮して理論的検 討を踏まえて実験式を提案し, 既往実験結果との良い一致を示して いる。また Yii ${ }^{8}$ は開口幅が壁面の全幅にわたる場合に対応した理論 式を提案している。これらの予測式は，必ずしも区画内を一様と見 なさず，高温の上部層と比較的低温の下部層とに分かれた状態を考 慮している点に特徴がある。

実際の火災では開口条件や可燃物等の配置に応じて火炎が偏在す
るため，ガス密度の分布は水平方向で多少なりとも変化する。火炎 などガス密度が周囲より小さい部分には浮力が働く。火炎部分の浮 力と区画内を巡る換気の流れとで方向が一致する場合，当該浮力が 換気を促進する可能性が考えられる。

筆者ら 9)が行った開口の少ない区画火災の模型実験では，燃焼率 の変化の要因として，火炎部分の浮力が換気量に影響した可能性が 考えられた。火炎部分の浮力が盛期火災の換気量に影響しうるのか 確認することが望まれるが，前述の様に盛期火㷋の換気量に関する 既往研究では，区画内一様と見なすか高さ方向の変化のみを考慮す ることが多く，火炎部分の浮力が換気量に与える影響についての検 討は殆ど行われていない。また，当該影響を検討寸るには天井高さ を変えるなどにより火炎部分が占める鉛直方向の高さを変えた実験 が有効と考えられるが，そのような実験報告は見当たらない。

そこで本研究では, フラッシュオーバー後の盛期火災で火炎や燃 焼反応後のガスなど（以降「高温ガス」）が床面の近くまで充満し， かつ火炎の分布に偏りがある状態を想定して，火炎部分に働く浮力 （以降「火炎浮力」）による仕事が換気量に及ぼす影響の有無を確認 することを目的として，火炎浮力の仕事が変わるように天井高さが 異なる実験で換気量を計測すると共に，火炎浮力を考慮した計算值 との比較を行った。

\footnotetext{
* 大成建設侏技術センター 工修

** 大成建設侏技術センター 博士 (工学)

*** 森林総合研究所 博士 (工学)

**** 早稲田大学理工学術院建築学科 教授. 工博

Technology Center, Taisei Corp., M. Eng.

Technology Center, Taisei Corp., Dr. Eng.

Forestry \& Forest Products Research Institute, Dr. Eng.

Prof., Faculty of Science and Engineering, Waseda University, Dr. Eng.
} 


\section{2. 火炎部分に働く浮力の仕事が換気量に及ぼす影響の考え方}

本研究では, 換気量に対して火炎浮力が影響するか或いは全く影 響しないのかを確認したい。そこで, 当該影響が曊れやすいと予想 される火災を想定して実験を行い, 換気量の変化の有無を確認する。 また, 実験值と当該影響を考慮した計算值とで実験条件が換気量に 与える変化を比較して, 実験条件間の差異が当該影響によるものか 否かを検討する。以降で, これらの実験・検討における火災・換気 の想定と火炎浮力の影響を考慮した換気量の計算について述べる。

\section{1. 想定する火災および換気}

本研究で想定する火災と換気をモデル化して図 1 に示す。室内が 高温のガスで充満した火災を想定する。更に, 火災室の代表的な換 気の流れとして, 開口下部から始まり, 床付近, 火炎, 天井付近そ して開口上部までを一巡する流れを考えることとする。

自由空間中の火炎が自身より密度の大きい周囲空気から浮力を受 けるように，火災室内の火炎も周囲ガスより高温で密度が小さいた め浮力を受ける。この火炎部分の浮力が, 前述の火災室内を一巡す る換気の流れを促進する方向に働くことに着目して, この仕事が大 きいほど換気量が増加する可能性があると考える。

この他に, 従来の研究と同様に火災室内外のガス密度差に起因す る開口部差圧も想定する。火災時のガス密度は絶対温度にほぼ反比 例し温度差が一定であれば高温ほど変化は小さいので，火災室内の 火炎の部分に働く浮力は開口部差圧に比べて小さくなるはずである。 従って, 本研究では, 火災室の換気の主要な原動力として開口部差 圧を，補助的なものとして火炎浮力の仕事を想定する。

\section{2. 火炎部分の浮力の仕事を考慮した換気量の計算方法注 1 )}

次章以降の実験で計測される換気量への火炎浮力の影響の有無を 判断する指標とするために当該影響を考慮した換気量の計算式を考 える。もし, 計測值と当該計算値とで実験条件間での増減の傾向が 一致し, かつ当該影響を無視すると一致しないのであれば, 火炎浮 力が換気量に影響したと判断して良いだろう。

次の 7 つ仮定をおいて図 1 のような火災室のモデルを考える。

仮定 1 : 火災室内部は定常状態に達しているものとする。

仮定 $2:$ 火炎を除いて区画内の温度は均一とする。

仮定 3 : 火炎内部の温度は均一とする。

仮定 4 : 火炎は天井に到達している。

仮定 5 : 区画に流入した空気は床付近から火炎に巻き込まれ天井ま で連行される。

仮定 6 : 火炎部分の浮力の仕事により発生した全てのエネルギーは 換気に使用される。

仮定 7 : 可燃ガスの発生量は換気量に比べて小さいため無視する。

なお，火炎は上昇に伴って周囲空気を巻き込むので、仮定 5 に従 うと火炎の浮力の仕事が大きめに見積もられる。また, 火炎浮力の 仕事により発生したエネルギーは摩擦など換気以外でも消費される が, 仮定 6 ではこれを無視して当該仕事の換気への関与を大きく評 価している。これらの仮定は，火炎浮力の仕事を強調することにな るが，ここでの目的である定性的議論の支障にはならないと考えて 設定した。故に, 以降の計算は汎用的ではなく実務には適さない。 前節の通り, 火災室内外のガス密度差による開口部差圧 $\Delta P$ およ び単位重量の気体に対して働く火炎部分の浮力・重力の仕事 $w_{f}$ (以

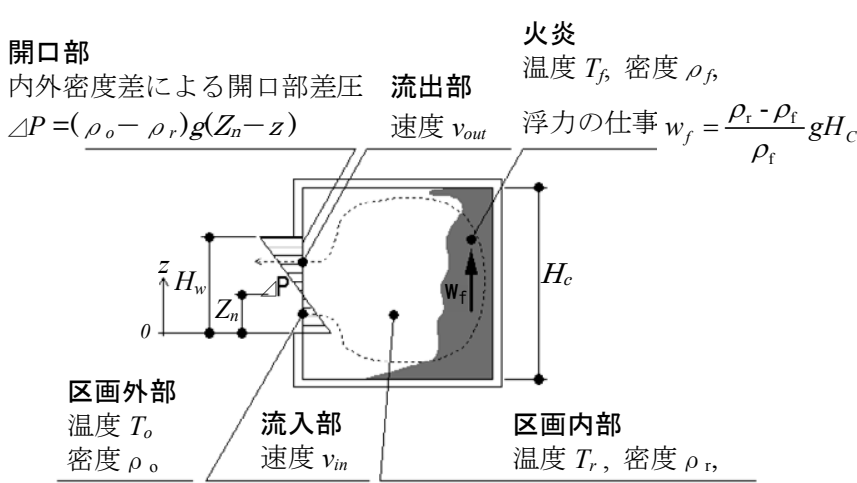

図 1 本研究で想定する火災および換気のモデル

降「火炎浮力の仕事」）により換気が行われると考える。 まず， $\Delta P$ を式(1)で表す。密度 $\rho$ は $\rho=353 / T$ とする（以降，同 じ)。

$$
\Delta P=\left(\rho_{0}-\rho_{r}\right) g\left(Z_{n}-z\right)
$$

長さ $H_{c}$ の火炎の部分には単位体積当たりで浮力 $\rho_{r} g$ が上向きに, 重力 $\rho_{f} g$ が下向きに㗢く。単位体積の気体が火炎の全長を移動する 間にこれらの力から受ける仕事は, 火炎高さを仮定 4 より $H_{c}$ として $\left(\rho_{r}-\rho_{f}\right) g H_{c}$ となる。単位重量当たりの火炎浮力の仕事 $w_{f}$ は下式と なる。

$$
w_{f}=\frac{\rho_{r}-\rho_{f}}{\rho_{f}} g H_{c}
$$

$w_{f}$ のうちで換気流入一関与する分を $w_{f, i n}$, 流出への分を $w_{f, o u t}$ とし, 仮定 6 より $w_{f, \text { in }}$ と $w_{f, \text { out }}$ の合計を $w_{f}$ とする。

$w_{f}=w_{f, \text { in }}+w_{f, \text { out }}$

$w_{f, \text { in }}$ と $w_{f, \text { out }}$ を含めて, 川越に倣って流入部と流出部の前後でベル ヌーイ式を適用して式(4)(5)を得る。

$$
\begin{aligned}
& \frac{1}{2} v_{\text {in }}{ }^{2}=\frac{\Delta P}{\rho_{o}}+w_{f, \text { in }} \\
& \frac{1}{2} v_{\text {out }}{ }^{2}=-\frac{\Delta P}{\rho_{r}}+w_{f, \text { out }}
\end{aligned}
$$

定常状態（仮定 1）かつ可燃ガスの発生量を無視できる（仮定 7） として，換気の質量流量（換気量）は流入と流出で釣り合うと考え る。開口流量係数が既知の值 $\alpha$ で与えられれば, 換気量 $M$ は流入 流出それぞれで式(6)(7)のように表せる。

$$
\begin{aligned}
& M=\alpha \int_{S_{\text {in }}} \rho_{o} v_{\text {in }} d S=\alpha \int_{S_{\text {in }}} \sqrt{2 \rho_{o} \Delta P+2 \rho_{o}{ }^{2} w_{f, \text { in }}} d S \\
& M=\alpha \int_{S_{\text {out }}} \rho_{r} v_{\text {out }} d S=\alpha \int_{S_{\text {out }}} \sqrt{-2 \rho_{r} \Delta P+2 \rho_{r}{ }^{2} w_{f, \text { out }}} d S
\end{aligned}
$$

ここ迄で未知数より数式が一つ少ないため解は得られない。そこ で中性帯高さ $Z_{n}$ は火炎浮力より開口部差圧に強く支配されると考 えて, $Z_{n}$ の計算に限り区画内を一様，すなわち $\rho_{r}=\rho_{f}=\rho_{a v e}$ として 
火炎浮力を無視 $\left(w_{f, \text { in }}=w_{f, \text { out }}=0\right)$ して式(1)(6)(7)から $Z_{n}$ を求める。 換気量 $M$ (および $w_{f, i n}, w_{f, \text { out }}$ ) は得られた $Z_{n}$ に基づいて式(3)(6)(7) を解けば求められる。なお, $M$ の算出についても前述の $Z_{n}$ と同様に $\rho_{r}=\rho_{f}=\rho_{\text {ave }}$ とすると川越のモデル1) と実質的に等しくなる。

\section{3. 実験概要}

\section{1. 実験条件および区画模型}

実験条件を表 1 に、実験で用いた区画模型を図 1 に示す。 区画模型は間口 $170 \mathrm{~mm}$, 奥行 $1400 \mathrm{~mm}$ で天井高さと開口形状は 実験条件によって異なる。当該区画模型は間口が狭いのが特徵的だ が，これは模型内部の流れを二次元に単純化し，想定火災（前章） に近づけることを意図している。当該区画模型の内装にはセラミッ クファイバーブランケットおよびセラミックファイバーボードを用 いた注2)。

実験 $1 \sim 4$ は丈 $300 \mathrm{~mm}$ の開口が一つ, 実験 $5 \sim 7$ は丈 $100 \mathrm{~mm}$ と丈 $50 \mathrm{~mm}$ の計 2 つ開口が上下に $300 \mathrm{~mm}$ 離れて設けられている (以降, 前者を「単一開口実験」, 後者を「二開口実験」と呼ぶ)。開 口幅は全て $170 \mathrm{~mm}$ (区画幅と同じ) とした。なお, 二開口実験で 上下の開口面積が異なるのは中性帯を下部開口上端から上部開口下 端までの間に位置させるためである。

火炎部分の浮力による仕事 $w_{f}$ (式(2)）が異なるときの換気量を計 測するために, 区画模型の天井高さ $H_{c}$ を単一開口実験では 900,750 , $600,450 \mathrm{~mm}$ の 4 条件，二開口実験では $900 ， 750,600 \mathrm{~mm}$ の 3 条件で変化させた。なお, 開口上部の垂れ壁の大きさは, 既燃ガス の外部への流れ出し易さに影響すると考えて, $150 \mathrm{~mm}$ で統一した。

全実験共通で，火源は幅 $170 \mathrm{~mm}$ （区画幅と同じ） ×奥行 $580 \mathrm{~mm}$ の面積を有するガスバーナーで, 燃料にプロパンを使用した。実験 を本研究の火災想定に近づけること, および火炎とそれ以外の部分 とを区別し易くなるように, 当該火源を開口から見て区画奥に設置
した。火源の公称発熱速度は単一開口実験で $42.1 \mathrm{~kW}(27 \mathrm{~L} / \mathrm{min})$ 、 二開口実験で $32.8 \mathrm{~kW}(21 \mathrm{~L} / \mathrm{min})$ である。これらは，開口因子か ら算定される区画内への流入空気量の全てが燃焼に寄与した場合の 発熱速度注3に相当する。燃料は当該目標值に達するまで段階的に目 標の $1 / 3$ ずつ $14 \sim 16$ 分間隔で増加させた。流量制御にはマスフロ ーコントロラーを使用した。

\section{2. 計測方法}

区画内温度, 開口部気流の動圧・温度および区画模型周囲の空気 温度（以降「外気温度」）を計測した注 4)。区画内温度は図 2 に示す 位置で $\mathrm{K}$ 型熱電対を用いて測定した。開口部気流の動圧および温度 は図 2 および図 3 の位置で $\mathrm{K}$ 型熱電対を取付けた二方向管注5)を用 いて計測した。なお, 熱電対先端と二方向管本体は接触していない。

本報で報告する計測值は、所定の燃料供給量に設定してから 12 分後のものである。但し, 単一開口実験における開口部気流の動圧・ 温度については, 計測点数に対して二方向管が不足していたため, 当該時刻を境に B3・B 4 を B $3{ }^{\prime} \cdot \mathrm{B} 4{ }^{\prime}$ に移動して計測した。これら については移動前・後の計測值を換気量の計算に用いた。

換気量は開口部で計測された動圧と温度から次のように算出した。 まず計測点を含むように図 3 の点線のように分割した開口の各部分 の流速 $v$ を式(8) で求める。次に流速 $v$ に気流密度 $\rho$ と各部分の面積 $A$ を乗じて式(9)のように各部分での流出・流入量 $M$ を求める。

$$
\begin{aligned}
& v=\sqrt{2 \Delta P_{b} / \rho_{b}} \\
& M=\alpha \rho_{b} v A=\alpha A \sqrt{2 \rho_{b} \Delta P_{b}}
\end{aligned}
$$

但し， $\alpha=0.65, \rho_{b}=353 / T_{b}$ とした。

最後に, 各部分の流出・流入量（式(9)) のうち流出量を合計して 区画の換気量とした。

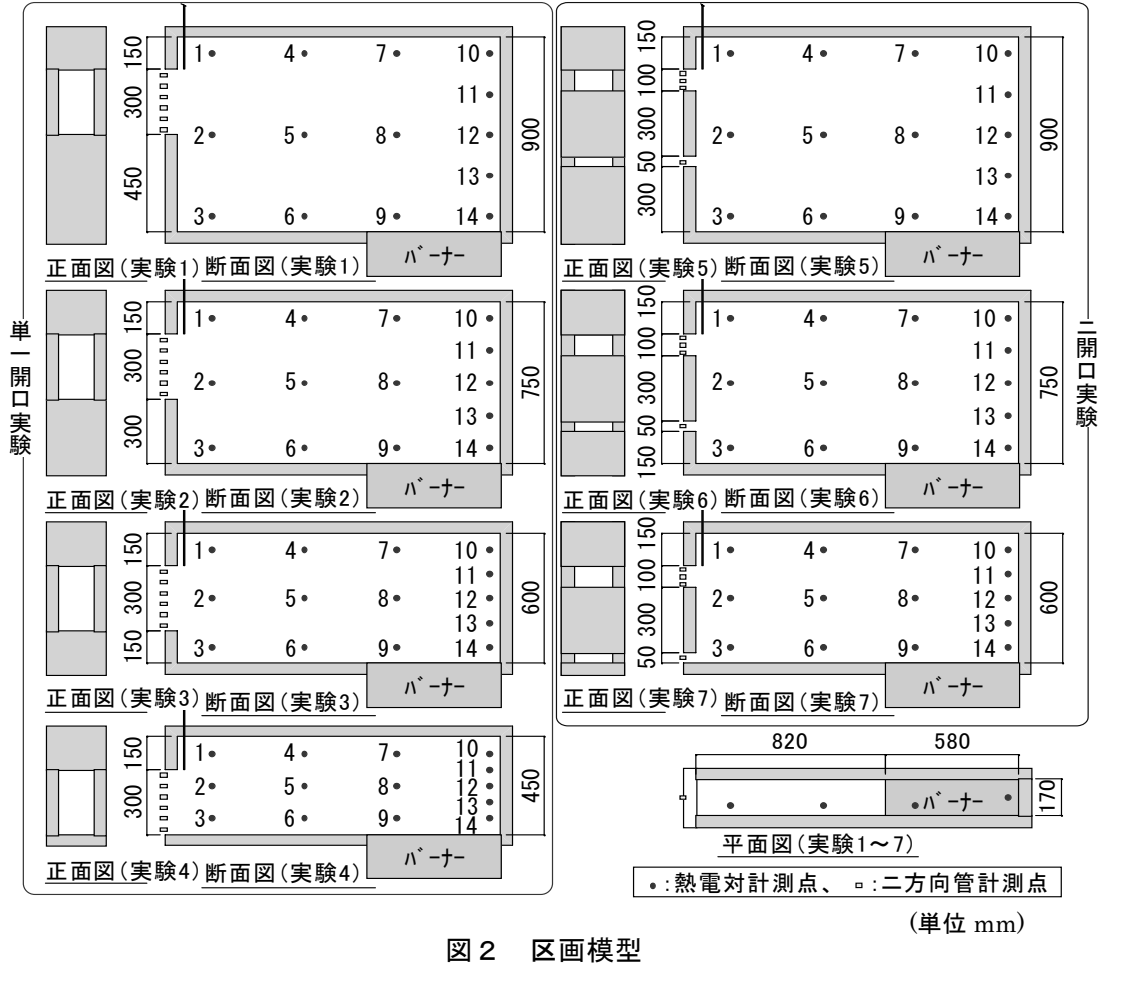

\begin{tabular}{|c|c|c|c|c|}
\hline & $\begin{array}{l}\text { 実験 } \\
\text { 番号 }\end{array}$ & 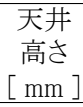 & $\begin{array}{c}\text { 開口寸法 } \\
\text { [ mm ] }\end{array}$ & $\begin{array}{c}\text { 公称 } \\
\text { 発熱速度 } \\
{[\mathrm{kW}]}\end{array}$ \\
\hline 単 & 1 & 900 & \multirow{4}{*}{$\begin{array}{ll}\text { 幅 } & 170 \\
\text { 丈 } & 300\end{array}$} & \multirow{4}{*}{42.1} \\
\hline & 2 & 750 & & \\
\hline \multirow{2}{*}{ 開 } & 3 & 600 & & \\
\hline & 4 & 450 & & \\
\hline 二 & 5 & 900 & \multirow{3}{*}{ 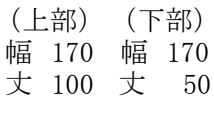 } & \multirow{3}{*}{32.8} \\
\hline 開 & 6 & 750 & & \\
\hline 口 & 7 & 600 & & \\
\hline
\end{tabular}

表 1 実験条件
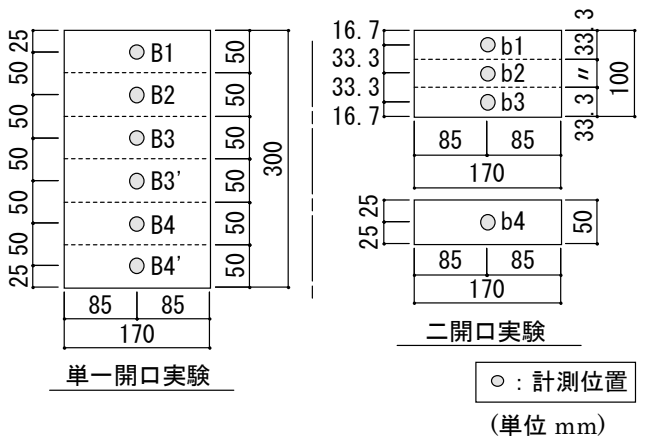

図 3 開口部の二方向管および熱電対の計測位置 


\section{4. 実験結果}

実験結果を表 2 および表 3 に示す。これらは各条件の所定の燃料 供給量に設定してから 12 分後の計測值である。区画内温度および 外気温度は 1 分間の時間平均, 開口部温度および動圧は 1.8 分間の 時間平均である。換気量は, 前述 (3.2.) の方法で計算した模型区 画開口部からの流出ガス量である。表 2 の火炎温度 $T_{f}$ は計測点 10 $\sim 14$ の平均, 区画内雾囲気温度 $T_{r}$ は計測点 $1 \sim 9$ の平均, 区画内平 均温度 $T_{a v e}$ は計測点 $1 \sim 10 \cdot 12 \cdot 14$ の平均である。前述（2.2.) の ように本研究では区画奥の火炎に働く浮力の仕事 (式(2)) に着目寸 るため $T_{f}$ には奥壁近傍の計測值を用いた注6)。

本研究では, 図 1 のように(1)室内が高温ガスで満たされ, かつ(2) 換気の流れが室内を一巡する火災を想定している。実験がこの想定 (1), (2)を満足したのか確認するために区画内温度（表 2 ）の分布を 図 4 に示す。同図(1)中の 1 14 の数字は計測点名称である。区画内 の 14 計測点の全実験を通じた最低值は $585^{\circ} \mathrm{C}$ （実験 6 計測点 3 ), $T_{a v e}$ の最低值は $934^{\circ} \mathrm{C}$ (実験 6) であった。 $300^{\circ} \mathrm{C}$ 以上の火災室温度 下では換気量の温度依存性は大きくないこと 4)を考えると, 換気量 を対象とするうえでは本実験の区画内温度は十分高く, 想定(1)を満 足したと言える。また, 全ての実験で奥壁近傍（計測点 10〜14）が 他の部分より高温で, 天井直下（計測点 1，4，7）では区画奥から 開口方向に温度が低下していることが図 4 から確認できる。これら は, 火炎が奥壁近傍を上昇し, その後, 天井直下を開口に向かって 流れたことを示しており, 想定(2)が満足されたと考えて良い。以上 より，全実験で本研究の火災の想定を満足したと言える。

本研究の焦点である換気量を比較するために全実験の計測值を図 5 に示す。単一開口実験（実験 1 4) では天井高さが最小の実験 4 が $0.0127 \mathrm{~kg} / \mathrm{s}$ で最小值となり, 天井高さが最大の実験 1 で最大值 $0.0161 \mathrm{~kg} / \mathrm{s}$ となったように, 天井高さが大きいほど計測值も大きく なった。単一開口実験での最大值と最小值との差は最大值を基準と して $20.7 \%$ と顕著である。一方, 二開口実験（実験 5～7）の最大・ 最小值はそれぞれ $0.0132 \mathrm{~kg} / \mathrm{s}$ （実験 5)・0.0128kg/s（実験 7）でそ の差は $3 \%$ とさいが, 単一開口実験と同様に, 天井高さの増加に 伴って換気量が増加する傾向が確認された。

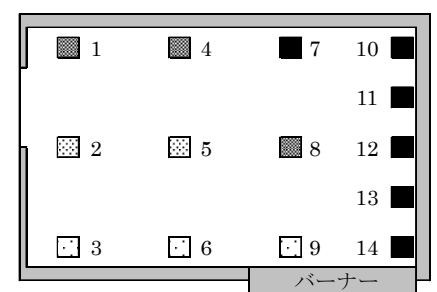

(1) 実験 1

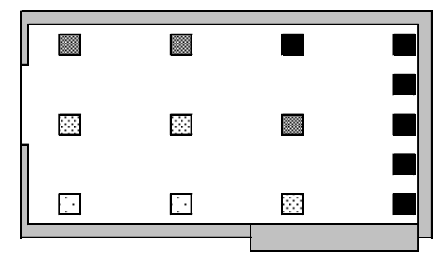

(2) 実験 2

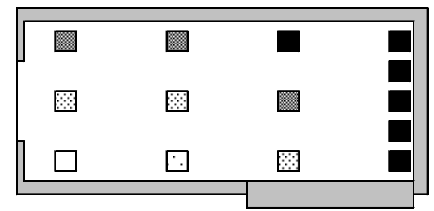

(3) 実験 3

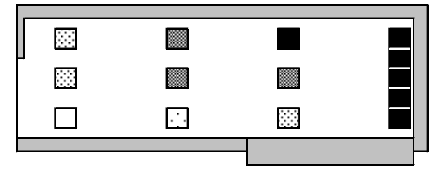

（4）実験 4

図 4 区画内温度分布

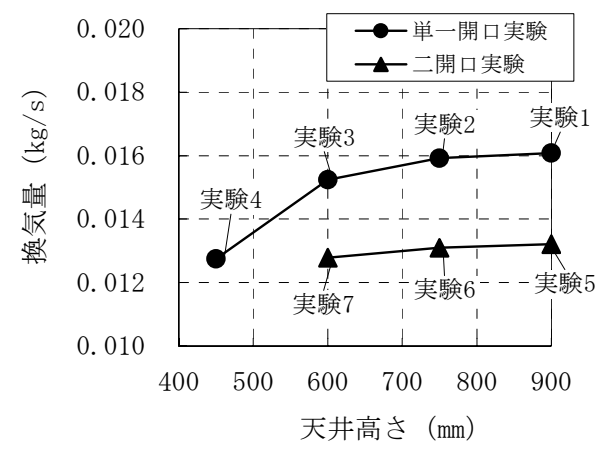

図 5 換気量計測值 (流出量)

表 2 区画内温度の計測結果

\begin{tabular}{|c|c|c|c|c|c|c|c|c|c|c|c|c|c|c|c|c|c|c|c|}
\hline & \multirow[b]{2}{*}{$\begin{array}{l}\text { 実験 } \\
\text { 番号 }\end{array}$} & \multirow{2}{*}{$\begin{array}{l}\text { 天井 } \\
\text { 高さ } \\
\text { [ mm ] }\end{array}$} & \multicolumn{17}{|c|}{ 区画内温度 $\left[{ }^{\circ} \mathrm{C}\right]$} \\
\hline & & & $\begin{array}{c}\text { 計測点 } \\
1\end{array}$ & 2 & 3 & 4 & 5 & 6 & 7 & 8 & 9 & 10 & 11 & 12 & 13 & 14 & $\begin{array}{c}\text { 火炎 } \\
T_{f}^{*}{ }^{* 1} \\
\end{array}$ & $\begin{array}{r}\text { 雰囲気 } \\
T_{r}{ }^{* 2} \\
\end{array}$ & $\begin{array}{l}\text { 平均 } \\
T_{\text {ave }} ※ 3\end{array}$ \\
\hline 単 & 1 & 900 & 975 & 836 & 689 & 1076 & 930 & 695 & 1164 & 992 & 798 & 1163 & 1218 & 1213 & 1215 & 1193 & 1200 & 906 & 977 \\
\hline 一 & 2 & 750 & 975 & 834 & 684 & 1073 & 944 & 691 & 1180 & 1023 & 804 & 1181 & 1245 & 1264 & 1273 & 1226 & 1238 & 912 & 990 \\
\hline 開 & 3 & 600 & 976 & 856 & 645 & 1077 & 938 & 731 & 1179 & 1041 & 852 & 1199 & 1274 & 1303 & 1299 & 1263 & 1268 & 922 & 1005 \\
\hline 口 & 4 & 450 & 950 & 906 & 588 & 1052 & 955 & 775 & 1146 & 1060 & 942 & 1168 & 1195 & 1211 & 1197 & 1166 & 1187 & 930 & 993 \\
\hline & 5 & 900 & 915 & 844 & 701 & 1002 & 878 & 681 & 1110 & 947 & 761 & 1103 & 1152 & 1161 & 1153 & 1120 & 1138 & 871 & 935 \\
\hline 開 & 6 & 750 & 915 & 844 & 585 & 1004 & 898 & 677 & 1109 & 980 & 752 & 1114 & 1176 & 1201 & 1203 & 1125 & 1164 & 863 & 934 \\
\hline 口 & 7 & 600 & 918 & 880 & 808 & 1026 & 947 & 753 & 1142 & 1057 & 861 & 1180 & 1244 & 1274 & 1291 & 1292 & 1256 & 932 & 1012 \\
\hline
\end{tabular}

表 3 外気温度, 開口部温度・動圧および換気量の計測結果

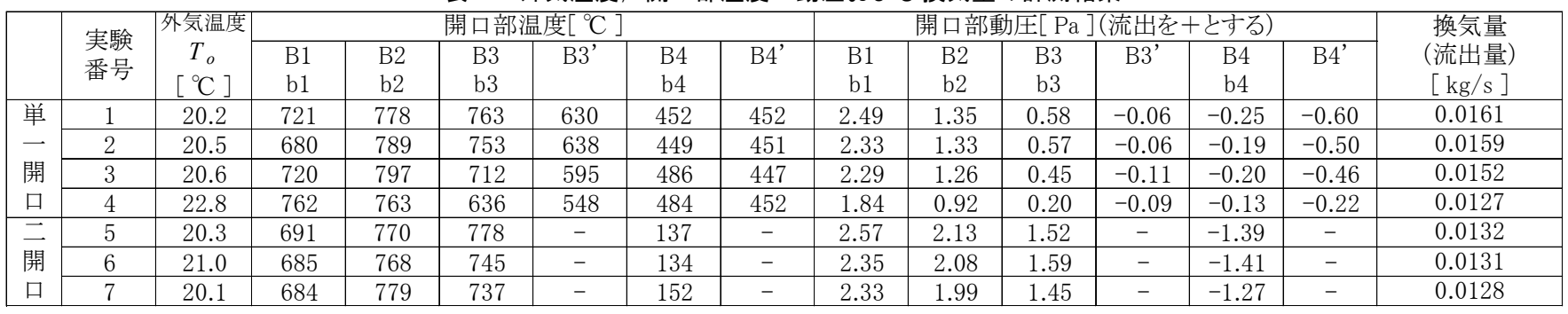




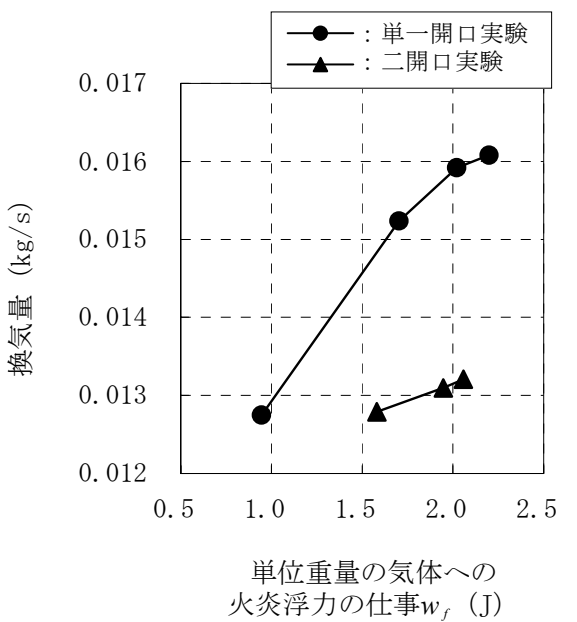

図 6 換気量の実験値と火炎浮力の仕事の計算値

\section{5. 考察}

前章の通り, 天井高さの増加に伴う換気量の増加が実験で確認さ れた。本章では, 当該実験結果について 2 章で述べた火炎浮力の仕 事による影響を検討する。なお, 本章の各計算で必要となるガス密 度は表 2 の火炎温度 $T_{f}$, 火災室䨌囲気温度 $T_{r}$, 火災室平均温度 $T_{a v e}$ および表 3 の外気温度 $T_{o}$ から算出する。

まず，各実験の換気量計測值（実験值）と火炎浮力の仕事 $w_{f}$ との 関係を図 6 に示す。 $w_{f}$ は式(2)で計算した。同図からは, 前述 (2.1.) で予想したように $w_{f}$ が大きいほど換気量が大きくなる関係が確認 できる。

次に, 火炎浮力の仕事を考慮する場合と火災室内を一様とみなし て火炎浮力を無視する場合の 2 通りについて 2.2.で述べた方法で換 気量を計算し実験值と比較する。計算結果を図 7 に示す。火炎浮力 を無視した計算值は天井高さが異なっても殆ど変化しないが, 火炎 浮力を考慮した計算值は実験值とほぼ平行に変化しており, 天井高 さの変化に伴った増減が良く一致している注 7)。

以上のことから, 本実験においては火災室（区画模型）内の火炎 部分の浮力の仕事が換気量の増加に寄与したと判断できる。また前 章の通り区画内平均温度は $934^{\circ} \mathrm{C}$ 以上であり比較的低温な床面近傍 の計測点でも $585^{\circ} \mathrm{C}$ 以上と十分高温であるから, 高温ガスで充満し た火災室の換気量に火炎浮力の仕事が影響することを確認したと言 える。

本実験で用いた区画模型は，換気量への火炎浮力の影響が大きく なるように意図されたものであり，建築物内の火災室として一般的 な形状ではない。開口も含めた火災室の寸法や可燃物配置といった 火災室の条件が異なれば，火炎浮力の仕事が換気量に影響する程度 も異なると予想される。本研究では，換気量の算定においてこれま で考慮されることのなかった火炎部分の浮力が換気量に影響しうる ことを確認したわけだが, 以上のような火災室条件への当該影響の 依存性の検討が今後の課題として挙げられる。

\section{6. まとめ}

本研究では, 高温ガスで充満した火災室内の火炎の部分に働く浮 力の仕事が換気量に与える影響の有無を確認するために, 間口 $170 \mathrm{~mm}$ ・奥行 $1400 \mathrm{~mm}$ の区画模型を用いて 2 種類の開口条件で天
井高さを変えた実験で換気量を計測すると共に，当該影響を考慮し た計算值との比較を行い，以下の結論を得た。

(1) 区画模型に幅 $170 \mathrm{~mm}$ ・丈 $300 \mathrm{~mm}$ の開口を設けた実験と，幅 $170 \mathrm{~mm}$ ・丈 $100 \mathrm{~mm}$ と幅 $170 \mathrm{~mm}$ ・丈 $50 \mathrm{~mm}$ の 2 つの開口を 設けた実験のそれぞれで, 天井高さの増加に伴って換気量が増 加することを確認した。

(2) 火炎部分に働く浮力の仕事を考慮した換気量計算值が，天井高 さの変化に伴った増減について実験值と良く一致した。一方, 当該影響を無視した計算值の増減は実験值と一致しなかった。 このことから天井高さの増加に伴う換気量の増加は火炎部分 の浮力の影響によるものであると考えられる。

以上の火災室の換気量への火炎部分の浮力の影響は，当該影響が 大きくなるように意図された実験および解析方法によって確認され たものであり，火災室条件によって変化することが予想される。火 災室条件の違いが当該影響に与える変化の把握が今後の課題として 挙げられる。

\section{謝辞}

本実験の実施に当たっては，早稲田大学（当時）の中嶋慶朗君に多 大な協力を頂いた。また，日本建築学会関東支部防火専門研究委員 会の鈴木圭一氏，新谷祐介氏，水上点睛氏および岸上昌史氏から貴 重なご助言を頂いた。ここに記すと共に関係各位のご協力に深く感 謝を表します。

\section{使用記号}

本文・図・表で使用している記号の意味は以下の通り。“( )”内は単位を表 すが，本文等に単位が記載してある場合はそちらに従う。

$A:$ 面積 $\left(\mathrm{m}^{2}\right), A_{W}$ : 開口面積 $\left(\mathrm{m}^{2}\right)$

$w_{f}$ : 単位重量の気体に対して働く火炎部分の浮力・重力の仕事 $(\mathrm{J})$

$w_{f, i n}, w_{f, i n}: w_{f}$ の内，換気の流入に係わる成分と流出に係わる成分(J)

$H_{\mathrm{c}}$ : 区画天井高さ $(\mathrm{m}), \quad H_{w}:$ 開口の縦寸法 $(\mathrm{m})$

$M:$ 換気量 $\cdot$ 流出量 $\cdot$ 流入量 $(\mathrm{kg} / \mathrm{s})$,

$\triangle P$ : 開口部差圧, 内部より外部の圧力が大きい場合を正とする $(\mathrm{Pa})$

$\triangle P_{b}$ : 動圧計測值 $(\mathrm{Pa})$

$S_{\text {in }}, S_{\text {out }}$ : 中性帯以下の開口面積と中性帯以上の開口面積 $\left(\mathrm{m}^{2}\right)$

$T:$ ガス温度 $(\mathrm{K})$ 
$T_{b}, T_{f}, T_{o}, T_{r}$ : 動圧計測点のガス, 火炎, 外気, 火災室雰囲気の温度 $(\mathrm{K})$

$Z_{n}:$ 中性帯高さ $(\mathrm{m})$,

$g:$ 重力加速度 $\left(\mathrm{m} / \mathrm{s}^{2}\right)$,

$v:$ 速度 $(\mathrm{m} / \mathrm{s}), \quad v_{\text {in }}, v_{\text {out }}$ : 流入部での速度と流出部での速度 $(\mathrm{m} / \mathrm{s})$,

$z:$ 開口下端からの鉛直距離 $(\mathrm{m})$,

$\alpha$ : 開口流量係数

$\rho:$ ガス密度 $\left(\mathrm{kg} / \mathrm{m}^{3}\right)$

$\rho_{b}, \rho_{f}, \rho_{o}, \rho_{r}$ : 動圧計測点のガス, 火炎, 外気, 火災室雾囲気の密度 $\left(\mathrm{kg} / \mathrm{m}^{3}\right)$

\section{注}

注 1）この計算式は，火炎浮力の仕事が換気量に与える影響の有無を確認す ることを目的として, 当該影響が顕著に顕れると予想される特定の状況を 想定したものである。従って, 汎用的ではなく, 実用には適さないことに 注意されたい。

注 2） 区画模型の壁，床および天井の構成材料は以下の通り。 壁（正面）: セラミックファイバーボード(以降「CBD」)（厚さ $25 \mathrm{~mm}$ ) 壁（背面）: CBD (厚さ $50 \mathrm{~mm}(25 \mathrm{~mm} \times 2$ 枚)

壁 (側面) : 鋼鈑（厚さ $3 \mathrm{~mm}$, 下地）＋セラミックファイバーブランケッ 卜 (以降「CBL」)（厚さ $50 \mathrm{~mm}$, 上貼り）

床 : $\mathrm{CBD}$ (厚さ $25 \mathrm{~mm}$, 下地) $+\mathrm{CBL}$ (厚さ $25 \mathrm{~mm}$, 上貼り)

天井 : CBD (厚さ $50 \mathrm{~mm}(25 \mathrm{~mm} \times 2$ 枚) $)$

注 3）単一開口実験（実験 $1 \sim 4 ） て ゙ は ~ 1500 A \sqrt{H_{W}}$ （ここで $A$ : 開口面積 $\left[\mathrm{m}^{2}\right]$, $H_{W}$ : 開口丈 $[\mathrm{m}]$ ) とした。また, 二開口実験（実験 5〜 7) では下式で求めた 換気量 ${ }^{10)}$ に単位重量当たりの空気の燃焼発熱量 $3000 \mathrm{~kJ} / \mathrm{kg}$ を乗じた值とし た。

$m=\alpha A_{a} \sqrt{2 \rho_{o} \Delta \rho g H}\left\{1+\left(\frac{T}{T_{o}}\right)\left(\frac{A_{a}}{A_{s}}\right)^{2}\right\}^{-\frac{1}{2}}$

ここで, $m$ : 換気量 $[\mathrm{kg} / \mathrm{s}], \alpha$ : 流量係数 $0.65, A_{a}$ : 下部開口面積 $\left[\mathrm{m}^{2}\right], A_{s}$ : 上部開口面積 $\left[\mathrm{m}^{2}\right], \Delta \rho$ : 火炎室内外密度差 $\left[\mathrm{kg} / \mathrm{m}^{3}\right], T$ : 㷋室温度 $1273[\mathrm{~K}]$, $T_{o}$ : 外部温度 $293[\mathrm{~K}], H$ : 上部開口中心から下部開口中心までの距離 $[\mathrm{m}]$

注 4） 3.2 .に述べた他に、随時、区画内ガスを $0.001 \mathrm{~kg} / \mathrm{s}$ 以下で吸引しガス 温度・濃度を計測した。また, 吸引管の詰まりを除去するために瞬間的に 空気を送り込んだ。これらの吸引・供給は流量が僅かであり, 本文記載の 計測值と時刻も異なっているため，本研究内容に与える影響は少ない。ま た得られた計測值も本研究目的と直接関係が無いため詳細な説明は控える。

注 5）本実験で使用した二方向管は，付図 1 に示すプローブと微差圧トラン スデューサ（Validyne, DP103-06）およびアンプライザ（クローネ， MS1001-4ch) で構成されており，フルスケール $22 \mathrm{~Pa}$, 計測精度はフルス ケールの $0.25 \%$ ケる。

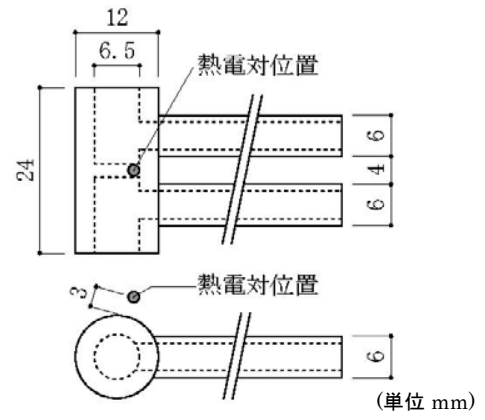

付図 1 二方向管プローブ

注 6) $w_{f}$ (式(2)）は浮力と気流の向きが一致する場所（気流が上向きの場所） で発生する。計測点 $4,7,8$ は周囲と比べて計測值が高く, 実際には火炎 が存在したと思われるが，気流の向きについては，4.実験結果・第 2 段落 の通り計測点 4,7 は水平に近いと考えられ, 計測点 8 についても直下で火 源に近い計測点 9 が計測点 8 より低温であることから鉛直方向に火炎は立 ち上がっていないと判断される。これらの計測点は $w_{f}$ には関与しないと考 え $T_{f}$ の算出には用いなかった。
注 7） 火炎浮力の影響を考慮した計算值と実験值の間に差が見られるが，こ の原因としては(1)計算では火炎浮力の仕事を大きめに算定していること, (2)幅が狭く奥行が大きい実験区画の壁面摩擦，火炎の上昇流の天井衝突や それに伴う曲がりおよび流入気流と流出気流のように向きが異なる気流同 土の干渉などによる圧力損失の影響を無視したこと，(3)実験では区画内外 からの放射の影響により熱電対による開口部気流温度の計測值に誤差が生 じた可能性があることが考えられる。原因が(1)の場合は 2.2.で述べた通り 本考察のような定性的な比較では大きな支障ではない。(2)については，壁 や天井の形状や表面状態は全実験で同じであり火炎の形状も 4.実験結果で 述べたように実験毎で大きくは変わらないので壁面摩擦や火炎の天井衝突 等による影響は全実験で同程度と考えられる。異方向の気流の干渉の影響 は，換気の流入・流出の位置関係が異なる単一開口と二開口とで比較すれ ば異なるが，同一開口条件では同程度と考えられるので，本考察のように 同一開口条件での比較に問題はない。(3)は，二方向管の熱電対から区画内・ 外を見る形態係数と区画内温度に依存するが，区画内平均温度（934〜 $\left.1012^{\circ} \mathrm{C}\right)$ が実験条件であまり変化せず, 同一開口条件での比較では形態係 数は変わらないので当該計測誤差は支障とならないと考えられる。

因みに, 単一開口実験と二開口実験とで計算值と実験值の大小関係が異 なる。この原因を把握するには更なる検討が必要であるが例えば以下の可 能性を考えることができる。

・単一開口実験では換気の流入部と流出部が接近しており，上記(2)の流入 気流と流出気流の干渉による圧力損失が大きかった。しかし計算值は圧力 損失を考慮していないため実験值より大きくなった。一方，二開口実験は 流入部と流出部が離れているため圧力損失の影響が小さく, 計測值と実験 值との差は比較的小さくなった。

・二開口実験では開口面積が小さいため, (開口面からやや外部よりに設置 された）二方向管の熱電対から区画外を見る形態係数が比較的大きく，上 記(3について区画内からの放射より区画外からの放射の影響が大きかった。 その結果, 気流温度が実際より低く計測され, 式(8)(9)から算出する実験值 が大きくなったため, 計算值は実験值よりやや小さな值（誤差 $4 \%$ 未満）と なった。

\section{参考文献}

1) Kunio KAWAGOE : Fire Behavior in Rooms, REPORT OF THE BUILDING RESEARCH INSTITUTE, No.27, pp.1-73, The Building Research Institute, Ministry of Construction, Japan, 1958.9.

2）川越邦雄，関根孝：壁体の熱伝導率のちがいによるコンクリート造建物 内の火災温度曲線の推定, 日本火災学会論文集, 第 13 巻, 第 1 号, pp.1-12, 1963.11.

3) JOHN A. ROCKETT : Fire Induced Gas Flow in an Enclosure, Combustion Science and Technology, Vol.12, pp.165-175, 1976.

4) Nakaya, I., Tanaka, T., Yoshida, M. and Steckler, K. : Doorway Flow Induced by a Propane Fire, Fire Safety Journal, Vol.10, pp.185-195, 1986.

5) K. D. STECKLER, J. G. QUINTIERE and W. J. RINKINEN : Flow Induced by Fire in a Compartment, Nineteenth Symposium (International) on Combustion, The Combustion Institute, pp.913-920, 1982.

6) K. D. STECKLER, H. R. BAUM and J. G. QUINTIERE : Fire Induced Flows trough Room Openings - Flow Coefficients, Twentieth Symposium (International) on Combustion, The Combustion Institute, pp.1591-1600, 1984.

7) J. G. Quintiere and Lei Wang: A General Formula for the Prediction of Vent Flows, Fire Safety Journal, Vol.44, pp.789-792, 2009.

8) Ee H. Yii : Vent Flows in Fire Compartments with Large Openings, Journal of Fire Protection Engineering, Vol.17, 2007.8.

9）中村正寿，道越真太郎，長谷見雄二：小開口区画における火災の燃焼率 に関する実験研究, 日本建築学会環境系論文集, 第 78 巻, 第 690 号, pp.613-622, 2013.8 .

10）田中哮義：改訂版建築火災安全工学入門，日本建築センター, 2002.1. 


\title{
EFFECT OF FLAME BUOYANCY \\ ON VENT FLOWS IN FULLY-DEVELOPED COMPARTMENT FIRES
}

\author{
Masatoshi NAKAMURA*, Shintaro MICHIKOSHI * , Daisuke KAMIKAWA*** \\ and Yuji HASEMI*** \\ * Technology Center, Taisei Corp., M. Eng. \\ ** Technology Center, Taisei Corp., Dr. Eng. \\ * Forestry \& Forest Products Research Institute, Dr. Eng. \\ **** Prof., Faculty of Science and Engineering, Waseda University, Dr. Eng.
}

\begin{abstract}
The objective of this study was to evaluate whether flame buoyancy increases vent flows in fully-developed compartment fires. Such vent flows are usually calculated from the hydrostatic pressure difference between the interior and exterior of the compartment. The interior environment is assumed to be uniform or two-layered with no horizontal distribution. However, in actual fires, flame distribution varies according to the opening conditions and displacements of fire loads. Most flames should appear along the main ventilation streamline. At points of upward-directed streamline, the vent flows may be enhanced by flame buoyancy. However, the effects of flame buoyancy have not been extensively investigated. In this study, we investigated flame buoyancy in a series of small-scale experiments, varying the ceiling height of the compartment and the number and size of the openings. The ceiling height of the compartment was assumed to be the flame height. Under all seven tested conditions, the width and depth of the compartment were retained at $170 \mathrm{~mm}$ and $1400 \mathrm{~mm}$, respectively. The compartments had either a single opening (width $\times$ height $=170 \mathrm{~mm} \times 300 \mathrm{~mm})$ or two openings $(170 \mathrm{~mm} \times 100 \mathrm{~mm}$ and $170 \mathrm{~mm} \times 50 \mathrm{~mm})$. The ceiling height was varied between $450 \mathrm{~mm}$ and $900 \mathrm{~mm}$ for the single-opening condition and between $600 \mathrm{~mm}$ and $900 \mathrm{~mm}$ for the two-opening condition. A propane burner with a width and depth of $170 \mathrm{~mm}$ and $580 \mathrm{~mm}$, respectively, was installed at the innermost region of the compartment. Using a mass flow controller, the nominal heat release rate was controlled at $42.1 \mathrm{~kW}(27 \mathrm{~L} / \mathrm{min})$ and $32.8 \mathrm{~kW}(21 \mathrm{~L} / \mathrm{min})$ for the single-opening and two-opening conditions, respectively, equivalent to combusting the entire volume of inlet air (predicted from the opening configuration). The vent flows were measured with bidirectional probes. In the single-opening compartment, the minimum $(0.0127 \mathrm{~kg} / \mathrm{s})$ and maximum $(0.0161 \mathrm{~kg} / \mathrm{s})$ vent flows was recorded at the lowest and highest ceiling height, respectively. Similarly, higher ceilings yielded stronger vent flows in the two-opening compartment, although the difference between the minimum $(0.0128 \mathrm{~kg} / \mathrm{s})$ and maximum $(0.0132 \mathrm{~kg} / \mathrm{s})$ vent flows was much smaller. High ceilings yielded greater vent flows through the openings under both opening conditions.

The work of flame buoyancy was calculated from the ceiling height and distribution of the fire temperature (measured by thermocouples). The vent flows were calculated under two conditions: calculation accounting for the effect of flame buoyancy and that assuming a uniform environment in the compartment.

Accounting for flame buoyancy increased the calculated vent flow under high ceiling conditions, whereas the constant-environment assumption predicted similar flows at all ceiling heights.

Since the calculated vent flows matched the experimental data better when flame buoyancy was considered, we conclude that flame buoyancy significantly affects the vent flows in compartments.
\end{abstract}

